\title{
Effects of Migration and Human Capital Formation in Albania
}

\section{Entela Kaleshi}

PhD Student, Faculty of Social Sciences, University of Tirana

\section{Abstract}

Albania has one of the world's highest emigration rates, relative to its population, at -3.3 migrants per 1,000 people, and a total migrant population of more than 1.25 million in 2014, according to UN Department of Economic and Social Affairs data. In 2010 Albania was granted with visa-free travel to the Schengen area and this also affected the crossing of the borders and the circular migration across the land border between Greece and Albania was for many years, one of the most significant irregular migratory flows across the EU's external borders. Although during the last years it is observed an increase number of return migrants, Albanian citizens continued to migrate and it is observed an increase of the number during 2014, and the new trend now is requesting asylum in EU member states increased during 2014. According to EUROSTAT data show that 65,000 Albanians applied for asylum in 2015, 55,000 of them sought asylum in Germany and 99 percent of Albanian asylum requests have been refused from European countries, half of them belong to the age group 18 - 34 years old. Due to the poor economic and living conditions in Albania, the labor market in Albania is still vulnerable and it affects the on-going migrant flows from Albania to the most developed labor markets of other countries. These migrant flows are directly linked with labor market development especially level of unemployment and poverty. Migration in Albania has major development impact and poverty implications in several levels. It has effects for individuals and their families, for origin and destination countries, and the national economy. At the individual level it shows that migrants benefit economically from their movements, their migration leads to better employment opportunities and income; at the household level in the home country migration reduces poverty at the family level and positively contributes to human capital formation, and improving education and healthcare conditions. Migration also has effects at the national level, bringing positive changes to the national economy.

Keywords: development, employment, human capital, migration, migratory flows 


\section{Introduction}

Today, we are living in an era that migration is one of the main topics of most local, national and international discussions. Encouraged by political and military conflicts, the pressures and developments that are undergoing the economies of the countries becoming increasingly globalized, climate change and the desire for a better life, more people than ever are moving and living beyond the borders of the country where they were born. Social systems are in motion, they evolve and change constantly through internal processes and because of their contact with the environment and other cultures. No society has ever been or will be completely frozen, although some cultures are seen as non-flexible, while others have been characterized by rapid changes. Immigration has become a very important factor in multi-cultural dynamics that drives society and brings economic, social and cultural change. Emigration moves people, changes society and social systems and makes the world seem smaller and more multi-cultural.

The fall of the communist regime in Albania in 1990 initiated a continued wave of immigration of Albanian population that continues till nowadays. The political and social instability, poor economic conditions and changes in government brought the largest flow of Albanian migration in modern times, with an estimated 300,000 individuals leaving the country from 1990 to 1992, primarily to neighboring Greece and Italy (Pastore, 1998; Piperno, 2002). The immigration flows towards other more developed countries in Europe and America continued with another peak during the non-stable situation created with the fall of pyramid schemes in 1997 that caused a political, social and economic crisis; and poverty and a high unemployment rate were the factors that contributed to the increase of the number of Albanian immigrants in other countries.

The figures from the Albanian Department of Emigration within the Albanian Ministry of Labour and Social Affairs estimated that, by 1999, there were 800,000 Albanians living abroad (Barjaba 2000). The majority of them, 500,000, were in Greece, 200,000 were in Italy, and the remaining 100,000 in other European countries and in North America. Some of the figures presented were likely to be underestimates, given the mobility of Albanian migrants, especially within Europe, and the rapid evolution of new migration channels and routes in recent years.

The number of Albanians in Greece appears to be high. Two large regularization programs about the legalization status of foreigners in Greece during 1998 and 2001 led to a total of 720,000 applications, of which Albanians represented approximately 60 percent, or 430,000. The 2001 Greek census shows 655,000 foreign residents, although critics contend that the number is more likely between 800,000 and 1 
million (OECD, 2002). Considering that 720,000 immigrants had applied for legal residence and that by the end of 2001, 585,000 immigrants had work permits, the critics' estimates are more likely to be correct. Estimates in literature suggest that more than half of the migrant population in Greece is Albanians. According to Labrianidis \& Hatziprokopiou (2005) the total number of Albanians in Greece is 450,000-550,000.

These figures are confirmed by the official statistics published by Greek Institute of Statistics, and as for 1.01.2015 the population living in Greece by country of birth (Albania, Montenegro, Macedonia, Serbia and Turkey) is 453,072 where Albanian are the largest community. Albanian immigrants in Greece are mainly families and together with all children born in Greece the figures confirm a number of nearly 500 000 Albanians.

Albania is one of the poorest in Europe, with a rising poverty rate of 17.9 percent and a youth unemployment rate of nearly 32.5 percent in 2014 (INSTAT, 2014). It currently has one of the world's highest emigration rates, relative to its population, at -3.3 migrants per 1,000 people, and a total emigrant population of more than 1.25 million in 2014, according to UN Department of Economic and Social Affairs data.

The migration policies of the Republic of Albania are various rules, strategies and documents reflected in the laws and decisions drafted and adopted for this purpose, in accordance with migration policies in general and with EU migration rules, aiming at minimizing migration costs and optimizing benefits, both for migrants and countries, through migration management, guaranteeing basic human rights and freedoms of migrants, combating illegal migration, etc.

The entire structure of basic legal migration documents per se consists of travel document policies, visa policy, admission policy, employment policy, residence policy, family reunification policy, unaccompanied minors policy, anti-war policy illegal migration, including illegal entry, illegal stay, illegal employment, marriage for migration purposes, a policy of protection of migrants' fundamental rights and freedoms, and personal data protection and migrant integration policy.

In a country such as Albania which has been affected a lot by immigration, it has been observed that the flow of human resources reduced socio-cultural productivity, but it improved the economic situation in the country, in the meanwhile immigrants face the challenge to adapt their socio-cultural system, values and cultural norms with the social codes and cultural norms of the hosting country, which are often very different from those of their country of origin. What happens more often is that these migrants as a response to the assimilation of their culture make partial adjustment of their culture to a new cultural environment and preserve the ties they have with their 
homeland by strengthening family links and relationships and use of new communication channels.

Migration policies of the Republic of Albania consist of the immigration and emigration policies expressed in the migration rules drafted and approved for this purpose, in line with the migration policy and migration rules of EU, aiming at minimizing the migration costs and optimising benefits, both for the migrants and countries, through the management of migratory flows, guaranteeing the fundamental human rights and freedoms of migrants, fight against illegal migration etc.

Migration policy in itself consists of travel document policy, visa policy, admission policy, employment policy, stay policy, family reunification policy, unaccompanied minors policy, policy of fight against illegal migration including illegal entry, illegal stay, illegal employment, marriage for purposes of documentation, carriers liability, return and admission policy, removal and expulsion policy, detention policy, policy of protection of fundamental rights and freedoms of migrants and personal data protection, policy of repressive measures and appeal, policy of integration of migrants, etc.

During the last years it is observed also a large number of returned Albanian who due to the economic crisis in Greece lost their jobs and have returned to Albania and sometime being engaged in seasonal works in Greece or immigrated to other European countries.

Due to the poor economic and living conditions in Albania, the labor market in Albania is still vulnerable and it affects the on-going migrant flows from Albania to the most developed labor markets of other countries. These migrant flows are directly linked with labor market development especially level of unemployment and poverty.

Migration in Albania has major development impact and poverty implications in several levels. It has effects for individuals and their families, for origin and destination countries, and the national economy. At the individual level it shows that migrants benefit economically from their movements, their migration leads to better employment opportunities and income; at the household level in the home country migration reduces poverty at the family level and positively contributes to human capital formation, and improving education and healthcare conditions. Migration also has effects at the national level, bringing positive changes to the national economy.

\section{Methodology}

This paper is part of my doctoral thesis research work about the cultural changes as a result of immigration of Albanian emigrants in Greece. It is based mainly on the 
research and participatory fieldwork with Albanian emigrants in Athens, Greece and review of reports, papers and other official documents in published in Albania, Greece and other countries. The research has combined qualitative and quantitative methods such as interviews, questionnaires, official statistics and documents review.

In the field of migration studies on the link between migration and other social factors such as poverty, inequality and human capital have been very focused in recent years, because population movements in a globalized world filled with great opportunities for mobility intensified and social networks have been added (Castells, 2006). Some scholars consider globalization as a force that damages national identity (Hobsbaum, 1992), while others argue that such developments reinforce national feelings (Smith, 2007). Cultural interactions are seen in different forms and contents, and as journalist Tomas Friedman says, "The world has become flat". Migration simplifies making new things possible both to the receiving and migrating populations, elements that often welcome, but are often ignored and attacked. It acts as a catalyst to bring about cultural changes because immigrants are often dissatisfied with cultural developments in their 'action' area.

Immigrants lose their common values, traditions, native songs, language, their cuisine, (Akhtar, 1999), as well as social status, important relationships, and in some cases, financial security (Yaglom, 1993) during the period they live in another place. While we also analyze mass migration cases (when migrants are removed together with their families) at different social times for a country, this process also involves the loss of many important elements for these people in the native culture they abandon, such such as family ties and relationships with humans argues (Marlin, 1994). In addition, immigrants may also lose the functions they have held in their country of birth, as well as feelings such as security and ties with others (Litjmaer, 2001). They lose a "world of theirs" that gave them a sense of security and how to lead their lives (Marcus, 2001).

As case studies were taken the stories of three families living and working in Greece (citiesof Athens, Larisa and Igoumenitsa) who also had close contacts with their relatives and other connections in Albania. I had personal contacts and several meetings with these families and the interviews were conducted during July - August 2015.

A set of questionnaires was filled by other immigrants in these three towns and in Albania during summer of 2015 when they were back for holidays. Access to interviewees was ensured following snowball sampling in combination with targeted sampling based on key informants input. There were three locations that were eventually chosen for fieldwork in Greece, Athens, Larisa and Igoumenitsa and two 
towns in Albania, Tirana and Saranda. The findings presented today are based on data gathered according the above sources.

\section{Literature Review}

Studies show that human capital development needs to be given special attention given its importance to economic and social development, especially today in the age of globalization. Unlike some years ago when markets were closed and entities were naturally creating favorable conditions for development after the competition was small, today technological developments and economic development require genuine specialists for every work process. The standard economic approach sees human capital as a set of skills and features that increase employee productivity. This definition is valid and in most cases is a practical and sufficient definition. However, it is good to make some distinctions of alternative ways of thinking about human capital based on the main theories in this area. A large number of theories have been used as a framework to describe the importance of education in economic development and entrepreneurship to achieve the success of both parties and business success in society.

A possible classification may be:

(1) Becker's views

The most well-known theory is that of Becker's human capital in 1975. This theory expanded the micro-level economic analysis of a number of human behaviors and suggested that knowledge and competences could enhance cognitive ability and lead to effective activities.

Scientific literature distinguishes between human capital generally referring to general education and practical experience and specific human capital, which refers to professional education and highly specific experiences closely related to particular applications related to a particular activity and context (Becker, 1975).

Human capital is directly beneficial to the production process. Explicitly speaking, human capital increases employee productivity in all tasks, though perhaps in different ways for different tasks, institutions or situations. In this respect, although the role of human capital in production processes can be quite complex, there is an understanding in which we can think of it as a one-dimensional object, stock of knowledge or skills of an individual.

(2) Gardener's views

According to this author we should not think about human capital as a onedimensional object, but as a whole with many dimensions and many kinds of skills. A 
simplified version of this approach would emphasize mental abilities against physical ones. This is defined as the Gardener approach based on the work of social psychologist Hoard Gardener, who contributed to the development of multiintelligence theory, particularly by highlighting examples of genres and famous personalities that have been very "unqualified" in some other dimensions.

(3) Schultz / Nelson-Phelps views

According to this author, human capital should be seen primarily as the capacity to adapt. According to this approach, human capital is particularly useful in dealing with "unbalanced" situations or in general in situations where there is a change and individuals have to adapt to this.

(4) Bowles-Gintis views

This author, when speaking of "human capital", speaks of the ability of individuals to work in organizations and obeying orders, ie the ability to adapt to the capitalist hierarchy of society. install "correct" ideology on individuals and such an approach to life.

\section{(5) Amartia Sen's views}

One of the most renowned social economists of recent years, Amartia Sen says that the central role of human capital accumulation affects social welfare in two different ways (Sen, 1997). According to Sen, on the one hand, it directly increases the human qualities and skills of employees for economic production and trade exchanges. On the other hand, human capital indirectly increases individual opportunities by giving people new opportunities and opportunities to enrich and make their lives better.

Thus, in order to understand the links between human capital accumulation processes and capacity building, we need to model how these two concepts are mutually related. By doing so, Sen says we need to use two well-known theories that explain what human abilities are and what human capital is.

\section{Albania, migration and human capital}

In Albania human capital development is shaped by various policies, including in particular education and training, employment policies and active labor market, and cross-cutting policy issues related to equality and social inclusion, competitiveness and innovation. The challenges of education and training in Albania are very important. By enhancing individual skills, competencies and knowledge, human capital accumulates and enhances individual freedom, enabling self-empowerment, civil involvement, and social participation to become more easily accessible. 
Many studies have underlined and proved that human capital is a key factor for entrepreneurship development, for example Corbett (2007) indicated that in the process of identifying opportunities for various economic investments recognition on the basis of core knowledge is very important because it serves as a base for interacting with new experiences and also used as a starting point to interpret and understand new developments.

One of the most important reasons for having pushed Albanians to other countries is to mention the economic ones, including improving living standards, better employment, and in some cases the reasons for a better education. Among the demographic data (INSTAT, 2013) most of the migrants were initially male and then family reunions took place taking place in the place where they were placed women and children. Primarily, employment is geared towards these sectors of construction, agriculture, manufacturing, hotel and for women more as domestic workers, the catering sector and hotelier.

Over the last two decades, Albanian migration has been closely linked with the family, and this connection has been the reason to strengthen and become the most important form of legal migration of Albanians to other countries. Different researchers agree with the fact that the family plays a decisive role in the migration process, given that changing the place of residence is an important event that has new opportunities and risks as well.

During the collection of data in the framework of the preparation of the study I have done with the Albanian emigrants, what I have noticed in the interviews conducted is that although these families are, in the first place, completely different, during meetings and conversations with them many things and similar models. They left Albania seeking work and better living conditions. They came from traditional family models in Albania, but during the migration process, many of these mechanisms have weakened, and the traditional pattern of family relationships and the strong internal and external pressures in the host country have brought about psychological, economic and social changes. These families today are more focused on their family well-being, but when other families are close to them, they support other families during the integration process. While new economic conditions have encouraged these families to act as separate economic units in the migration process. This can be identified as a mobility to achieve an improvement in social and economic conditions and an improvement in working conditions, thus benefiting from participation in social security schemes, access to formal employment and having a job with a status and higher salary. 


\section{Presentation of the case studies}

\section{Case Study 1 - Family A / Edmond, 54 and Sanije, 43}

They are a couple being married for 25 year and they have two daughters. First time Edmond went in Greece was in 1991, at that time he was nearly 30 years old. After the fall of communism and the opening of borders between the two countries he and his two older brothers immigrated illegally to Greece. Their home village was only three kilometers from the Greek border, but they never had tried to pass the border during the communist regime. On the first ten years he went Greece and came back to Albania on irregular bases and without his wife. As an illegal emigrant without documents and work permission he worked only on black and his wife and the two daughters were living in Albania with the money earned by him. When the Greek government started the process of legalization of immigrants Edmond started to prepare the documents helped by his Greek boss. He paid his taxes and insurance and after a year was provided with one year permission to work on agricultural jobs, because his boss was a farmer and the insurances were paid to OGA the National Authority about Agriculture pensions. After that he prepared the family unions documents and took the documents for his wife and his daughters. Every year they renew the papers and the last round there were provided with documents issued for 10 years. During the last years the family live between Albania and Greece, one daughter is student in an University in Tirana, the other one is married and the couple go to work in Greece on seasonal bases. Sanije goes during the summer to work as cleaning lady in a hotel, Edmond for summer agricultural works (collecting fruits, ect) and their daughter who is a student as a seller in a shop, and during the winter they both collect oranges. They have a rented house in Igoumenitca, town where they stay in Greece and they have renovated their house in Albania with the money earned during these 25 years of working in Greece. Also they have planted oranges in Albania and during the last years have started to sell their products. They have a lot of Greek friends and pay visits during national and religious celebrations, speak Greek and know very well Greek customs and Greek traditions.

\section{Case Study 2 - Family K/Jorgo 67, and Melita 63}

Jorgo could not find work in Albania and he went in Greece in 1991 in Athens together with his cousins, and stayed in a neighborhood where other relatives were living there too. After a difficult period living alone or with other cousins and friends he brought his wife through a visa for health treatment. At that time his two sons were University students at and joined their parent during the summer holidays to earn extra money for their studies. He worked for more than ten years as a builder and carpenter, and the rest of years up to now he is working in a gas station. His wife has 
worked as a housekeeper or taking care of elder women when most of the time she also sleep in the houses where she works. They both didn't speak a word in Greek when arrived in Greece and now speak and understand very well. Melita has more contacts with the everyday life in Greece and her language is fluent, and she says that no one can understand that Greek is not her native language. She has worked in families with a good social status in Greece and this has helped with her language skills not only speaking Greek, but also reading and writing it fluently. During one of the meetings with her she was reading a book of the French writer Emil Zola in Greek. This family told me that they now are very integrated in the Greece, although the beginning was very difficult. Jorgo also has changed his Muslim name, Xhelal in order to find a job when he arrived in Greece. He says that during the first months when he was looking for a job and was asked about his name, no one offered him a job, at the moment when he decided to say that his name was Jorgo, this was not a problem anymore. The problem came after when he had to document his health and pension insurances as all the taxes were paid in the name of Jorgo, and in 1998 when he started to prepare the papers to be legal immigrant in Greece he came back in Albania and changed his name in the Albanian register from Xhelal to Jorgo. At the beginning he didn't feel good about this, and blamed the Greek for being racists, but now he says that he is used with both names, familiars and relatives in Albania call him Xhelal, and friends and relatives in Greece call him Jorgo. Jorgo admits that the attitude of Greek toward Muslim names has changed a lot, and it is not the same situation as it was 25 years ago. When I asked them what keeps them now in Greece at their age, they are not anymore younger and their children live in Albania, their answer was that the social insurance contributions they have paid towards their pension for at least 15 years now is something that cannot be overlooked and on 2016 they will be retired according to the Greek legislations. Another reason that keeps them living in Greece as retired persons is the health system of Greece. They both suffer from different chronic illnesses, Melita has made 8 different surgeries and now she is under doctors' supervision for the last and very difficult intervention she had. They both are insured in Greece and the medical treatments are for free. They say that this cannot happen in Albania, the health system there is corrupted and there are not such treatments as they receive in Greece.

\section{Case Study 3 - Family D / Romeo 44, and Lola 37}

They were in love in a very young age, Romeo 22 and Lola 15, none of their families wanted them to marry at that age and they decided to escape and go and live together in Greece. They went in Larisa, a town in the Northwest of Greece because some cousins of Romeo were living there and helped him to accommodate and after few days they rented a house and started to live together. Romeo found a job in construction and Lola cleaned houses. This was the beginning of their life as 
immigrants and as a family in Greece. They were working on long hours and saved money and moved in a better house and with a better standard of living. Romeo is from Greek minority in Albania and Lola comes from a Muslim family, but they were accepted very well in the Greek community in Larisa, they also were baptized as Christian Orthodox. They were both very open and easy-going and made a lot of Greek friends in Larisa. This network of friends helped them to find jobs easily and to be paid in time for the work done. In 1999 they had a son that according the Orthodox religion was named as Romeo's father and was baptized by a Greek family. They visited their families in Albania twice a year, during Christmas and in Easter Holidays. The Greek crises affected their family and Romeo couldn't find a permanent job and started to work on occasionally bases and after this they decided to invest their savings on their home village. Their parents had some land and they planted in it oranges and mandarins. Romeo have started to come more often in Albania to take care about the plants and in the last years he also takes his son during holidays to help him and "transmit to him the values of work and to be responsible for their property".

\section{The role of families in the migration process}

Over the past two decades, family-linked migration is the most important form of legal migration of Albanians in other countries. Various researchers agree that the family plays a decisive role during the migration process, given that changing one's country of residence is a critical event entailing both opportunities and risks. Although the above families are very different, during the meetings and conversations with them there are observed lots of similar things and patterns. They left Albania looking for a job and better living conditions. They came from traditional families in Albania, but during the emigration process, various mechanisms have weaken the traditional system of family relations and strong internal and external pressures have changed their psychological, economic and social field. These families are more focused on their family well-being, they support other families during the integration process and the economic circumstances have encouraged families to act as an economic unit in the migration process. Two different researches realized in two main urban areas in Greece indicate that it is an increasing socio-economic mobility and an improve of community's working conditions that include the participation in the social security schemes, access to formal employment and jobs of higher status and salary.

\section{Integration Strategy}

These three cases, questionnaires filled, previous researches and published articles show that although there are many differences in the way families and Albanian immigrants are integrated in Greece, there are very positive trends in the integration processes. The second generation of children that have born in Greece or have gone 
there at a young are decisive for a successful integration. The elements that were identified in the interviews and questionnaires as important for the integration are:

(a) communication and language; (b) socializing with Greek / other families (c) having knowledge about customs, traditions and value systems of hosting country; (d) involvement in social activities especially those regarding school education of children, (e) demonstrations of non-conflict and low ethnic identity; and (f) contacts with familiars in Albania.

\section{Relations with the homeland - transnational families}

But in the same time when they develop integration strategies immigrants develop also a set of informal interpersonal ties, family and friendship ties in Albania, these social networks link them to their home and familiars in Albania and help them to overcome difficulties and the integration problems. Regular contacts in the form of visits, videos, emails and telephone calls; financial remittances; practices of building houses in the homeland has fostered the social ties and cultural practices with the home country. The findings show that these families build in different levels their lives between Greece and their native home towns and villages. The three families and their friends and relatives have various mechanisms to hold symbolic and real relations with the old homeland. Albanian families have established a life with a cultural belonging in Greece and maintain continuous cross-border contacts with their beloved persons in Albania. These took the form of repeated visits, regular contacts, exchanging gifts and photos and occasionally receiving family visitors from Albania (Al-Ali 2002a; 2002b; 2002c; Parreñas, 2005). Trips to Albania are also very popular and sometime spend summer holidays with their grandparents in Albania.

\section{Use of Albanian language}

In migration literature native language is considered among the key cultural tools employed in displacement to remember 'home' away from home (Kershen, 2006). The case study families use Albanian during their daily communication and practice it at home and less in the public spaces. It is observed also a use a both languages in the same time known as the phenomena of 'double consciousness' in the diasporic realm (Gilroy 1993). Adults speak Albanian to each other at home and children speak Greek with their Greek-born Albanian friends, while parent-child communication is on / between both languages. Parents, relatives and friends actively encouraged children's contacts with the ethnic language confirming the role of the wider family and 'ethnic enclaves' in initiating the second generation to bilingualism (Kershen, 2000). 


\section{Conclusions}

Emigration has had a major impact on the development of human capital in Albania. Employment of Albanian emigrants in the developed economies of host countries has provided them with a general culture of work management, work ethics, knowledge of new sectors of the economy, knowledge of the latest technology and technology. Their return over the past few years to the Albanian economy is accompanied by the transfer of those skills and knowledge they have received while they have lived and worked in migration.

An immigrant in the process of integration into the host culture faces such challenges as "minorities", "foreigners" and "emigrants" who often have a negative tone in their native language. and how these identity losses occur widely varies depending on the circumstances of the migration, the personality of the person and the difference that may exist between the cultures of origin and the host. But even though it is accepted by all that immigrants fit and integrate with culture of their host country, it is also acceptable that emigration poses a threat to the host nation's national identity.

A country that has a large influx of immigrants has many difficulties as a result of the removal of labor force and especially of a young age, bringing enormous consequences to the human capital of a country. Researchers, economists, theorists and different authors join in the idea that human capital is of particular importance to the development of each sector in a given country. If institutions possess professional, skilled and conscious employees in what they do, then chances of getting high scores are great. Moreover, the literature argues that there is a fair link between staff qualification and the outcomes of the institution where they work, thus affecting the economy of the country as a whole, so human capital also has a macroeconomic impact. This is because human capital is very important as it develops or not an entity.

This paper summarizes Albanian families' experiences, integration and cultural changes while sharing their lives between their everyday time in Greece and family connections in Albania. They have formed and developed adaptation and survival strategies from the beginning of their migration till the establishment in the host country and they have learned the host country social and institutional environment and the related immigration policy measures and implementation practices. After that they have adapted their plans and developed coping strategies in response to the social and institutional environment of the country of destination. Their narratives have showed the limitations and opportunities which they actively integrate into their everyday life experience and their understanding of themselves, their country of origin and the host country. 
This immigration experience is reflected on these families' identity; how they see themselves within the context of the host country, their identifications with the country of origin and their individual self-understanding. These families living between two countries, keep the contacts with their familiars in Albania, project a life if they will be back in Albania and in the same time adapt and integrate to their everyday life in the host cultural setting.

A special thank you goes to the three Albanian families for accepting to participate in this research project.

\section{References}

[1] Al-Ali, N. 2002a Gender relations, transnational ties and rituals among Bosnian refugees, Global networks 2: 249-262.

[2] Al-Ali, N. 2002b Trans-or a-national? Bosnian refugees in the UK and the Netherlands. In: N Al-Ali and K Koser (eds) New approaches to migration? Transnational communities and the transformation of home, 96-117. London: Routledge.

[3] Al-Ali, N. 2002c Gender relations and transnational ties among Bosnian refugees. In: D Bryceson and U Vuorela (eds) Forging new frontiers in Europe: transnational families and their global networks, 83-102. Oxford.

[4] Akhtar, S. (1999). Immigration \& Identity: Turmoil, Treatment \& Transformation. Northvale, NJ: Jason Aronson.

[5] Berry, J. W. (1997). Immigration, acculturation and adaptation. Applied Psychology, 46(1), 5-68.

[6] Berry, J. W., Phinney, J. S., Sam, D. L., \& Vedder, P. (2006). Immigrant youths: acculturation, identity, and adaptation. Applied Psychology, 55(3), 303-332.

[7] Blundell, R. Dearden, L. Meghir, C. Sianesi, B. (1999), Human Capital Investment: The Returns from Education and Training to the Individual, the Firm and the Economy, Fiscal Studies (1999) vol. 20, no. 1, pp. 1-23

[8] Brüderl, J., Preisendörfer P., and Ziegler,R. (1992): Survival Chances of Newly Founded Business Organizations. American Sociological Review, 57: 227-242.

[9] Castells, M. (2004). The power of identity the information age: Economy, society and culture. New York, NY: Wiley-Blackwell.

[10] Chen, P., Wilmoth, J., 2004. The effects of residential mobility on ADL and IADL limitations among the very old living in the community. Journal of Gerontology Series B: Psychological Sciences and Social Sciences Online 59, 164-172.

[11] Corbett, M. (2007). Learning to leave: The irony of schooling in a coastal community. Black Point, NS: Fernwood. 
[12] Costa, D., Kahn, M., 2000. Power couples: Change in the locational choice of the college educated, 1940-1990. Quarterly Journal of Economics 115, 12871314.

[13] Davidsson, Per \& Honig, Benson L. (2003) The role of social and human capital among nascent entrepreneurs. Journal of Business Venturing, 18(3), pp. 301331.

[14] De Soto, H., P. Gordon, Gedeshi,I. and Sinoimeri, Z. 2002. Poverty in Albania. A Qualitative Assessment. Washington DC: World Bank Technical Paper 520.

[15] Dearden, L. (1998), 'Ability, families, education and earnings in Britain', Institute for Fiscal Studies, Working Paper no. 98/14.

[16] Florida, R. (2002) The economic geography of talent. Annals of the Association of American Geographers, 92: 743-755.

[17] Florida, R. (2003) The Rise of the Creative Class. New York: Basic Books.

[18] Friedman, L.T (2006). The Lexus and the Olive Tree - Understanding Globalization. Anchor

[19] Gellner, E., Nations and Nationalism, Oxford, Basil Blackwell, 1983.

[20] Gilroy, P. 1993, The black Atlantic: modernity and double consciousness. Cambridge, Mass: Harvard University Press.

[21] Glaeser, E. L. (1999) Learning in Cities. NBER Working Paper 6271, Cambridge, MA.

[22] Glaeser, E. L. (2005a) Smart Growth: Education, Skilled Workers and the Future of Cold-Weather Cities. Cambridge, MA: Harvard University, Kennedy School, Policy Brief PB-2005-1.

[23] Glick-Schiller, N. Basch, L. and Blanc-Szanton, C. (eds) 1992. Towards a transnational perspective on migration. New York: New York Academy of Sciences.

[24] Harvey, L., Moon, S. and Geall, V with Bower, R., 1997, Graduates' Work: Organisation change and students' attributes. Birmingham, Centre for Research into Quality (CRQ) and Association of Graduate Recruiters (AGR).

[25] Henry, H. M., Stiles,W. B., \& Biran, M.W. (2005). Loss and mourning in immigration: Using the assimilation model to assess continuing bonds with native culture. Counselling Psychology Quarterly, 18(1), 109-119.

[26] Hobsbawm, E. (1992). Nations and nationalism since 1780. Cambridge: Cambridge University Press.

[27] Jacobs, J. (1969) The Economy of Cities. New York: Random House.

[28] Kelly, A. U. (2009). Migration and Education in a Multicultural World_Culture, Loss, and Identity, Palgrave Macmillan (2009).

[29] Kershen, J. A. (ed.) 2000 Language, Labour and Migration. Hants: Aldershot. 
[30] Kershen, J. A. A 2006, The Migrant at Home in Spitafields: Memory, Myth and Reality. In: K Burrell and P Panayi (eds) Histories and Memories: Migrants and their History In Britain, 96-113. London: Tauris Academic Studies.

[31] King, R. and May, N. 2002 "Of Myths and Mirrors: Interpretations of Albanian Migration to Italy.” Studi Emigrazione 145(39):161-200.

[32] King, R., May, N.and Dalipaj, M. 2003. Exploding the Migration Myths. Analysis and Recommendations for the European Union, the UK and Albania. London: The Fabian Society and Oxfam.

[33] Labrianidis, L. and Lyberaki, A. (2001) Albanian Immigrants in Thessaloniki: Paths of Prosperity and Oversights of their Public Image. Thessaloniki: Paratiritis.

[34] Labrianidis, L. \& Hatziprokopiou, P. (2005), The Albanian migration cycle: migrants tend to return to their country of origin after all, in R. King, N. Mai and S. Schwandner-Sievers (eds), The New Albanian Migration, Brighton: Sussex Academic Press, pp. 93-117.

[35] Labrianidis, L. and Lyberaki, A. (2004) 'Back and Forth and In Between: Returning Albanian Migrants from Greece and Italy', Journal of International Migration and Integration 5 (1):77-106.

[36] Lijtmaer, R. M. (2001). Splitting and nostalgia in recent immigrants: Psychodynamic considerations. Journal of the American Academy of Psychoanalysis, 29(3), 427-438.

[37] Lucas, R. (1988) On the mechanics of economic development. Journal of Monetary Economics,22: 3-42.

[38] Massey, Douglas. et al.1993, "Theories of International Migration - A Review and Appraisal." Population and Development Review 19(3):431-466.

[39] Marlin, 0. (1994). Special issues in the analytic treatment of immigrants and refugees. Issues in Psychoanalytic Psychology, 16(1), 7-16.

[40] Marcus, P. (2001). Loss and renewal. In P. Suedfeld (Ed.), Light from the ashes (pp. 421-429). Detroit, MI: The University of Michigan Press.

[41] Mehta, P. (1998). The emergence, conflicts, and integration of the bicultural self: psychoanalysis of an adolescent daughter of South Asian immigrant parents. In S. Akhtar and S. Kramer (Eds.), The colors of childhood: Separationindividuation across cultural, racial and ethnic diversity (pp. 129168). Northvale, NJ: Jason Aronson, Inc.

[42] Mirsky, J. (1991). Language in migration: separation and individuation conflicts in relation to the mother tongue and the new language. Psychotherapy, 28(4), 618-624.

[43] Murray, J. (2001). Loss as a universal concept: A review of the literature to identify common aspects of loss in adverse situations. Journal of Loss and Trauma, 6(3), 219-241. 
[44] Nicholson, B. 2001. 'From Migrant to Micro-entrepreneur: Do-It-Yourself Development in Albania', South-East Europe Review, 4(3): 39-41.

[45] Nicholson. 2002. 'The Wrong End of the Telescope: Economic Migrants, Immigration Policy, and How it Looks from Albania', The Political Quarterly, 73(4): 436-444.

[46] Oswell, D. (2006) Culture and Society An Introduction to Cultural Studies. SAGE Publications.

[47] Parreñas, S. Rachel. 2001 Servants of globalization: women, migration and domestic work. California: Stanford University Press.

[48] Pastore, F. 1998, Conflicts and Migrations. A Case Study on Albania. Written Briefing for the Conflict Prevention Network of the European Commission. Rome: CeSPI.

[49] Piperno, F. 2003, Remittances Enhancement for Local Development in Albania: Constraints and Opportunities. Working Papers 4/2003. Rome: CeSPI.

[50] Portes, Alejandro. 1995, "Economic Sociology and the Sociology of Immigration: A Conceptual Overview." Pp. 1-41 in The Economic Sociology of Immigration, edited by Alejandro Portes. New York: Russell Sage Foundation.

[51] Smith, A. D. (2007). Nationalism in decline? New York, NY: Routledge.

[52] Stiles, W. B. (2002). Assimilation of problematic experiences. In J. C. Norcoss (Ed.), Psychotherapy Relationships that Work (pp. 357-365). Oxford: Oxford University Press.

[53] Stiles, W. B., Morrison, L. A., Haw, S. K., Harper, H., Shapiro, D. A., \& FirthCozens, J. (1991). Longitudinal study of assimilation in exploratory psychotherapy. Psychotherapy, 28(2), 195-206.

[54] Wilmoth, J., 1998. Living arrangement transitions among America's older adults. The Gerontologist 38, 434-444.

[55] Yaglom, M. (1993). Role of psycho-cultural factors in the adjustment of Soviet Jewish refugees: Applying Kleinian theory of mourning. Journal of Contemporary Psychotherapy, 23(2), 135-145.

[56] Yong C, Stuart S. R., Local amenities and life-cycle migration: Do people move for jobs or fun?, Journal of Urban Economics 64 (2008) 519-537.

[57] Vijay K. M. Human Capital-Based Strategy for Regional Economic Development, Economic Development Quarterly, Vol. 13 No. 3, August 1999 203-216, DOI: 10.1177/089124249901300301.

[58] Vullnetari, J. 2009, "Women and migration in Albania: A view from the Village”, International Migration, Volume 50, Issue 5. 